\title{
“ZA JEDNE ON JE HEROJ, A DRUGIMA JE ZLOČINAC" - GAVRILO PRINCIP U POPULARNOJ KULTURI 100 GODINA NAKON SARAJEVSKOG ATENTATA
}

KATARINA LUKEC

43231 Ivanska, Ivana Mažuranića 95

klukec@ffzg.hr
DOI: $10.17234 /$ SEC.28.11

Prethodno priopćenje

Primljeno: 9. 5. 2016.

Prihvaćeno: 18. 6. 2016.

Ovaj rad nalazi se u otvorenom pristupu i može se distribuirati u skladu s odredbama licencije CC BY-NC-ND 4.0 HR

Autorica u ovom radu prikazuje kako se lik $i$ djelo Gavrila Principa iskorištava u popularnoj kulturi usredotočujući se na pjesme koje tematiziraju Sarajevski atentat dvaju bosanskohercegovačkih bendova: Zoster i Dječak iz Vode. Kroz analizu pjesama i komentara na YouTube mreži, propituje se i istražuje uloga popularne kulture u društvenom sjećanju.

Ključne riječi: Gavrilo Princip, popularna kultura, Balkan, društveno sjećanje

\section{UVOD}

Sarajevskim atentatom naziva se događaj koji se zbio 28. lipnja 1914. godine u istoimenom gradu, tada austrougarskom, danas bosanskohercegovačkom. Skupina mladih revolucionara rasporedila se po sarajevskim ulicama između novonastalih povorki ljudi kako bi izvršila atentat na austrougarskog prijestolonasljednika Franju Ferdinanda koji je bio u službenom posjetu Sarajevu. Nakon prvoga neuspješnog pokušaja bacanja bombe na njegov automobil, nešto kasnije atentat uspijeva mladiću Gavrilu Principu koji hitcima iz pištolja ubija prijestolonasljednika i (slučajno) njegovu ženu (Horvat 1967:11). Sarajevski atentat tada je poslužio kao izlika za Prvi svjetski rat (Ibid. 12) koji je započeo upravo austrougarskim objavljivanjem rata Srbiji (Ibid. 129).

Sto godina nakon toga događaja priča Gavrila Principa nanovo je aktualizirana u pjesmama dvaju alternativnih bendova s područja Bosne i Hercegovine. Prva pjesma, naziva Gavrilo, izašla je 2014. u lipnju kao 
najavljujući singl albuma Srce uzavrelo mostarskog rock benda Zoster. Autor teksta i glazbe jest pjevač benda Mario Knezović. ${ }^{1}$ Druga pjesma, Sasvim neobični slučajevi, objavljena je također 2014. godine i to točno na dan obljetnice Sarajevskog atentata - 28. lipnja, a album na kojem se nalazi Sretan rad objavljen je 2015. Autor ove pjesme jest Dječak iz Vode (DiV), točnije Edin Džambić, eksperimentalni rock kantautor iz Brčkoga koji trenutačno živi i stvara u Zagrebu, a projektu DiV naknadno se pridružila i njegova supružnica Ljubica (Lju) Anđelković Džambić. ${ }^{2}$

Oba se benda i u ostatku glazbenog opusa bave političkim temama, ${ }^{3}$ a na stotu godišnjicu Sarajevskog atentata (i početka Prvoga svjetskog rata) odali su počast Gavrilu Principu, ${ }^{4}$ bosanskom Srbinu, počinitelju atentata. Zbog toga ga je zapamtio čitav svijet te je postao jedan od simbola Balkana. Pozitivan ili negativan, teško je na prvu reći. Upravo zato ovaj rad prikazuje na koji se način (re)konstruira sjećanje na lik i djelo Gavrila Principa, ali i kako se ono interpretira u različitim diskursima. Rad također donosi specifičan pristup popularnoj (odnosno rock) kulturi i analizira je kao dio društvenog sjećanja, ali i njegova (re)kreiranja. Društveno sjećanje, najšire rečeno, obuhvaća predodžbe o prošlosti konstruirane u sadašnjosti (Connerton 2004:6), a s obzirom na to da je popularna kultura definirana svakodnevicom i suvremenošću, ${ }^{5}$ upravo je zanimljivo uočiti kako se u njoj manifestira društveno sjećanje, tj. kakve predodžbe o prošlosti ona

\footnotetext{
${ }^{1}$ Izvor: http://www.muzika.hr/clanak/50712/albumi/zoster-ogolio-svakog-od-nas.aspx (pristup 28. 12. 2015.).

${ }^{2}$ http://djecakizvode.wix.com/div-djecak-iz-vode\#!blank/c10kj (pristup 28. 12. 2015.).

${ }^{3}$ Npr. DiV u pjesmi Tri metra od straha tematizira situaciju sa sirijskim izbjeglicama i ISIL-om te je objavljuje u rujnu 2015. nakon što je Mađarska postavila žice na granici sa Srbijom kako bi spriječila izbjeglički val. S druge strane, Zoster naizgled sličnu temu bilježi 2012. u pjesmi Izbjeglica gdje donosi individualnu priču izbjeglice. No, njihova najotvorenija pjesma po političkom pitanju jest Neformalna himna BiH gdje Knezović provokativnim nazivom donosi ironični tekst o političkoj situaciji Bosne i Hercegovine.

${ }^{4}$ Dok Mario Knezović u intervjuu jasno navodi da je povod objavi pjesme stota godišnjica atentata [http://www.hercegovina.info/vijesti/show/showbiz/zoster-opjevaoslavnog-gavrila (pristup 28. 1. 2016.)], o Džambićevoj motivaciji možemo samo suditi iz simboličke objave na točan datum obljetnice jer na internetu nema sličnih intervjua.

${ }^{5} \mathrm{http}: / / w w w . e n c i k l o p e d i j a . h r / n a t u k n i c a . a s p x ? i d=49511$ (pristup 7. 2. 2016.).
} 
donosi i na koji način. Taj odnos popularne kulture i društvenog sjećanja proučavam kroz Gavrila Principa, odnosno njegov ulazak u popularnu kulturu koncentrirajući se na spomenute dvije rock pjesme te reakcije na jednu od tih pjesama u obliku komentara na društvenoj mreži YouTube, pri čemu je YouTube zapravo mjesto potrošnje popularne kulture (Usp. Hall 2006:127-128).

\section{METODOLOGIJA}

Metodologija koju primjenjujem u ovom $\operatorname{radu}^{6}$ jest analiza diskursa. U najširem smislu, to bi značilo da promatram kako se jezik koristi da potakne aktivnosti, perspektive i identitete (Gee 1999:4). S obzirom na to da se svaka analiza diskursa razlikuje jer se prilagođuje vrsti diskursa $\mathrm{i}$ problemima koji nju zanimaju (Ibid. 5), ona je uvijek interdisciplinarna, ali i kombinacija više različitih pristupa (Jørgensen i Phillips 2002:1). U ovom radu analiziram dvije vrste tekstualnih žanrova, stoga se i pristup svakom od njih razlikuje. Konkretno, prvi dio analize utemeljen je na tekstovima pjesama Sasvim neobični slučajevi i Gavrilo, a drugi dio na YouTube komentarima pjesme Gavrilo. ${ }^{7}$

Polazište prvog dijela analize (tekstovi pjesama) jest promatranje glazbe kao komunikacije čija ideologija djelomično proizlazi iz umjetničkih namjera muzičkih stvaralaca te iz estetika njihovih muzičkih formi (Frith 1987:19). S time da će ovdje biti analiziran samo tekst, tzv. lakši put interpretacije (Ibid. 227), jer su izostavljeni izvedbeni kontekst i glazba koji su sinergijski povezani s tekstom, te se tekst promatra samo kao književni

\footnotetext{
${ }^{6} \mathrm{Rad}$ je dorađena verzija seminarskog rada napisanog u sklopu kolegija Antropologija društvenog sjećanja pod mentorstvom dr. sc. Nevene Škrbić Alempijević pri Odsjeku za etnologiju i kulturnu antropologiju Filozofskog fakulteta Sveučilišta u Zagrebu (akad. god. 2015./16.). Kao takav, prezentiran je na godišnjem skupu Hrvatskoga etnološkog društva Veliki rat-etnološki, folkloristički i kulturnoantropološki aspekti, 4. ožujka 2016. godine.

${ }^{7} \mathrm{~S}$ obzirom na to da je Zoster poznatiji i zastupljeniji izvođač na sceni no DiV koji je ipak dio underground scene, video za njihovu pjesmu privukao je veću pozornost, pa shodno tomu polučio i veći broj reakcija u obliku komentara. S druge strane, video Sasvim neobični slučajevi zasad je bez komentara. Stoga moja analiza uključuje isključivo reakcije na pjesmu Gavrilo.
} 
(Frith, prema Duda 2006:99) pokušavajući iz njega odgonetnuti “društvenu snagu" (Shuker, prema Duda 2006:99).

Druga analiza u radu bavi se komentarima na YouTube mreži koje su ljudi s područja BiH, Hrvatske i Srbije ostavljali na pjesmi Gavrilo. Ova analiza na tragu je tzv. diskurzivne psihologije ${ }^{8}$ jer su sadržaji komentara formirani kao iskazi svakodnevice (Jørgensen i Phillips 2002:20) te upućuju na činjenicu da su mišljenja pojedinaca, pa i njihovi identiteti, formirani unutar socijalne interakcije (Ibid. 108). Ovdje nije cilj autore komentara svrstati po njihovu ideološkom svjetonazoru nego identificirati diskurzivne prakse kroz koje su kategorije njihovih (ideoloških) identiteta formirane (Ibid. 107-108), a to ću učiniti prije svega kroz lik Gavrila Principa. Točnije, u tom dijelu analize izdvajam različita viđenja njegova lika svrstavajući ih u pet kategorija.

Analiza diskursa treba imati neku svrhu (Gee 1999:8), a ovdje je ona u službi tumačenja različitih interpretacija G. Principa: zašto i kako do njih dolazi? Odnosno, ono što u ovom radu povremeno nazivam praznim prostorom koji je nastao oko lika i djela Gavrila Principa, može se tumačiti tako da se lacanovski pojam praznog (odnosno lebdećeg) označitelja koji je razvio Laclau pojednostavljeno preslika na G. Principa, pa bi značilo da je on označitelj bez označenog, odnosno njegovo značenje ovisi o diskursu koji će u njega investirati svoje značenje (Usp. Laclau 2007:37-40). Upravo takav prazan prostor oko lika i djela Gavrila Principa iskoristili su i sebi prilagodili spomenuti bendovi. No ovdje će biti prikladnije ${ }^{9}$ ako taj prazni

\footnotetext{
${ }^{8}$ Diskurzivna se psihologija baš kao i kritička analiza diskursa (engl. critical discourse analysis - CDA) zanima za upotrebu jezika u društvenim interakcijama, ali njezin cilj nije proučavati promjene u društvenom diskursu općenito nego istražiti kako ljudi koriste dostupne diskurse u kreiranju slike svijeta i identiteta kroz interakcije. U ovom pristupu analizi diskursa pojedinac nije samo proizvod diskursa nego i njegov proizvođač (Jørgensen i Phillips 2002:7).

${ }^{9}$ Prazni označitelj dolazi u paru s lebdećim označiteljem i to u diskurzivnoj teoriji hegemonije koju su postavili Laclau i Mouffe u svom čuvenom djelu Hegemony and Socialist Strategy. Lebdeći i prazni označitelj zapravo su ista stvar, samo označavaju različite procese, tj. svaki označitelj je prazan, ali lebdećim se naziva u kontekstu borbe značenjskog punjenja različitih diskursa (Laclau, prema Breglec 2015:5). Odnosno, lebdeći označitelj je ono značenje koje neki diskurs investira u označitelja (Jørgensen i Phillips 2002:27), koje nastoji “pobijediti” u borbi značenjskog punjenja. Uz to, u ovoj teoriji
} 
prostor tumačim kao sastavni dio lika Gavrila Principa kroz prizmu heroja. Točnije, heroji su znakovi (Peirce, prema Fikfak 2014:8) koje svaki primatelj i pošiljatelj shvaća drugačije, pripisuje mu različito značenje i formira ga na različite načine, svaki put iz druge perspektive. Isti heroj može značiti i dobro i loše, i poštenje i zlo; može biti kamen spoticanja u društvu, ali i rješenje, odgovor na neki društveni problem (Fikfak 2014:8). Principa stoga možemo tumačiti kao prizmu u kojoj se različiti načini interpretiranja (nacionalne) povijesti križaju, ali i suprotstavljaju zbog svojih ideoloških opozicija (Belaj i Škrbić Alempijević 2014:81).

Osim analize diskursa, u ovom radu konzultirala sam se ponajprije s literaturom o društvenom sjećanju, ali je bilo potrebno posegnuti i za literaturom iz područja balkanskih studija te onom o političkim simbolima koja je nerijetko upravo dio jedne od dva prethodno spomenuta područja. Osim toga, za aktualizaciju podataka ili njihovu provjeru koristila sam internetske izvore, od kojih se najveći broj odnosi na članke o glazbenim izvođačima.

\section{GAVRILO PRINCIP U ROCK GLAZBI}

Iako se rock i pop glazba često shvaćaju u dihotomiji (Frith 1987:18) pri čemu se rock tretira kao manje komercijalan, on će se ipak ovdje promatrati kao dio popularne glazbe u širem smislu, jer ono što nju definira jest namjena širokom tržištu. Iako postoje autori koji možda ne stvaraju namjenski za široku masu, stoji činjenica da je njihova glazba dostupna svima. Nitko nije spriječen da posluša jednom objavljenu pjesmu ili album (Ibid. 14-15), posebice ako su objavljeni na internetu.

spominju se prošivni bodovi: privilegirani označitelji koji djelomično fiksiraju značenje (Ibid. 28), a predstavljeni su upravo praznim ili lebdećim označiteljima. Razlog zbog kojeg ne promatram Gavrila Principa primarno kao praznog/lebdećeg/privilegiranog označitelja jest što se ta teorija odnosi na hegemoniju društva i tzv. hegemonijske borbe koje nastoje fiksirati lebdeće označitelje. Lebdeći označitelji predstavljaju nemoguće ideale kojima se teži i obično se primjenjuju na "velike" riječi: sloboda, jednakost, pravda, red... [http:// gong.hr/media/uploads/gong_ljetna_skola_-_durin.pdf]. Stoga mi se čini da bi bilo previše pojednostavljeno prikazati Gavrila Principa u ovom kontekstu čisto na temelju osnovne definicije, a rad se također ne fokusira na hegemoniju kao temu. 
Pjesme koje su u središtu moje analize na poseban način tematiziraju Sarajevski atentat. Riječ je o dva izvođača koji dolaze iz geografski, politički i povijesno različitih bosanskohercegovačkih gradova. Oni su 100 godina nakon atentata odlučili reinterpretirati najslavniji događaj svoje zemlje. Pjesmu Sasvim neobični slučajevi izvodi Dječak iz Vode, točnije Edin Džambić, koji dolazi iz Brčkoga. To je grad u sjeveroistočnom dijelu $\mathrm{BiH}$, ujedno i centar Distrikta Brčko, zasebne administrativno-upravne jedinice u Bosni i Hercegovini koja ne pripada nijednom od dvaju entiteta na koje je ova zemlja podijeljena (Federacija Bosne i Hercegovine i Republika Srpska). Njime naime upravljaju mjesne i državne vlasti, uz pomoć međunarodne zajednice kao supervizora. ${ }^{10} \mathrm{~S}$ druge strane, pjesmu Gavrilo izvodi bend Zoster koji dolazi iz Mostara, grada na jugu $\mathrm{BiH}$, središnjeg i najvećega hercegovačkog grada.

U ovoj analizi stoga donosim izdvojene dijelove tekstova pjesmama pokušavajući ih tumačiti kao dio cjeline, ali opet i odgonetnuti njihovu "društvenu snagu" (Shuker, prema Duda 2006:99) kao pojedinih entiteta koristeći pretpostavljene referencije iz društveno-povijesne stvarnosti, ali i tumačeći pjesničke metafore. Učinit ću to kroz spominjanje sličnosti i različitosti između pjesama koje ću odmah zatim potkrijepiti i objasniti.

Osim zajedničke teme, sličnost pjesama leži i u izmještanju priče. Naime, podaci navode da Princip u to vrijeme nije živio u samom Sarajevu nego je tamo privremeno boravio kod jednog od suradnika u atentatu, a da je rodom iz sela Obljaj u zapadnom dijelu BiH (Pfeffer 1938:27). No u pjesmi Gavrilo njegova majka (kao simbol rodnog mjesta) i život smješteni su u samo Sarajevo (“... zamislite Sarajevo. Ustaj sine, majka zove, doručak na stolu čeka"). Dok u ovoj pjesmi to nije bitno za samu radnju, kod Edina Džambića izmještanje poprima jaču simboliku. Naime, atentat postavlja u rodno Brčko ("Ferdinand nam dolazi, vidovdansku trku sprema usred Brčko Distrikta"). Ovim ludičkim činom Sarajevski atentat čak na tren više nije "sarajevski" iako ga poslije opet "vraća" ("u vihoru strašnog rata usred grada Sarajeva"). Možda ga je smjestio u Brčko upravo zato što tamo i dan-danas vladaju "strane sile"; dakle, ništa se nije promijenilo ni samim Sarajevskim atentatom koji se ponekad predstavlja upravo kao čin borbe

\footnotetext{
${ }^{10} \mathrm{https}$ ///bs.wikipedia.org/wiki/Br\%C4\%8Dko (pristup 31. 12. 2015.).
} 
protiv stranih sila. Gavrilov čin bio je uzaludan; štoviše, još je više nahranio zapadne negativne stereotipe o Balkanu (Usp. Todorova 2015:198). Tako je nepromjenjivost balkanske sudbine još jedna zajednička paralela ovih pjesama; naime, Knezović navodi da je Gavrilo svojim činom krenuo "na put bez povratka", a i mi svi zajedno s Gavrilom, štoviše, “još i danas hodimo njime".

Jedna bitna razlika, naizgled samo formalna, leži u tome što je Džambićeva pjesma napisana kao zaokružena cjelina, sa svojim početkom i krajem, dok Zoster pjesmu samo započinje kao naraciju ("Tog jutra rano je ustao ...") koju ostavlja nedovršenom aludirajući na spomenutu balkansku nepromjenjivu sudbinu. Tekstopisac Mario Knezović u svojoj nedovršenoj naraciji iskorištava prazni prostor oko lika i djela Gavrila Principa, ne zauzima strogo afirmativan ili negativan stav, a ključni stihovi pjesme u središte stavljaju BiH i, čini se, sve njezine stanovnike (“Jer kad se u Bosni plus i minus izjednači. I kad se um pomrači. I niko nikom ništa ne znači”). Nejasna slika oko G. Principa preslikava se na cjelokupnu zemlju sa svoja tri konstitutivna naroda i dva entiteta iako o tome nema eksplicitnog govora. U cijeloj priči ipak je najvažniji pojedinac i njegovi osjećaji ("U svakom slučaju, njegovo srce je ranjivo. U svakom slučaju, srce uzavrelo").

S druge strane, Edin Džambić u svojoj pjesmi izvrće značenje Gavrila Principa nastavljajući ludičko izmještanje priče s početka pjesme; on G. Principa, inače bosanskog Srbina pravoslavne vjeroispovijesti (Ibid.), veže uz pojmove islamske konotacije - Gavrilu u njegovoj priči majka sprema sutliju $^{11}$ te svraća do šehera ${ }^{12}$ kupiti svom tetku Adilu sirutke. On u toj priči, čini se, parodira sam događaj i Principov lik kao srpskog junaka. Naime, u njegovoj verziji Gavrilo ne ubija Franju Ferdinanda nego s njim bježi na Kosovo ("Otrčao Gavro Princip što je brže mogao, zagrlio Ferdinanda: Bježimo na Kosovo"). Ne samo da su pobjegli na Kosovo čije je osvajanje Srbija slavila te 1914. (Mićanović 1965:85) i oko čijih odnosa i danas postoje peripetije, nego su pobjegli kao ljubavni par ("I dan danas kruži priča o toj strasnoj ljubavi između nam dva mladića"). Nadalje, Džambić ovaj par rodbinski povezuje s osuđivanim srpskim zločincima ("Mladić

\footnotetext{
${ }^{11}$ Sutija - riža na mlijeku.

12 Šeher - grad, velika varoš.
} 
Ratko sin im prvi, Karadžići rođaci, Slobo časni kum s krštenja”). Kako bi dodatno zakomplicirao cijelu priču oko naše interpretacije njegove pjesme, autor se gradi izjavom kakvu znamo viđati u parodijama: "Svi likovi i događaji u ovoj priči su izmišljeni, plod autorove mašte. Svaka sličnost sa stvarnim likovima i događajima je slučajna."13

Mario Knezović, kao što sam rekla, ne zauzima afirmativan ili negativan stav oko Gavrila Principa ("Za jedne on je heroj, a drugima je zločinac. A možda negdje na pola puta, njegova duša luta"), no svjestan je kako je prošlost kojoj pripada i Gavrilo dio kaotične sadašnjosti, a ostavljajući priču nedovršenu kao da nagoviješta nastavak te kaotičnosti. Pjesmom Sasvim neobični slučajevi također se nagoviješta uska veza prošlosti i sadašnjosti, što je direktna posljedica činjenice da sadašnjost utječe na našu percepciju prošlosti, ali i obrnuto: spoznaje o sadašnjosti ovise o našem znanju o prošlosti (Connerton 2004:6). Edin Džambić Gavrila Principa aktualizira u najkontroverznijim stihovima u pjesmi, koji su ujedno i završni, gdje ga rodbinski povezuje s osuđivanim srpskim zločincima i kontroverznim ličnostima: Ratkom Mladićem, porodicom Karadžić te Slobodanom Miloševićem kojeg naziva nadimkom "Slobo" (kao što i Gavrila oslovljava "Gavro"). Džambićeva pjesma jake simbolike ostavlja mjesta za različite interpretacije, a iznijet ću dvije koje gotove stoje u opreci. Prva bi bila da on u ovoj pjesmi intenzivira odnose između Bošnjaka i Srba koristeći pojmove iz islamskog svijeta, s jedne strane, te likove iz novije srpske povijesti, s druge. No umjesto da proziva srpske zločine počinjene nad Bošnjacima tijekom povijesti, on ih smješta u fikcionalni svijet gdje oni to uopće nisu. On kao da se igra, ne sa značenjem Gavrila Principa, nego sa srpskom kolektivnom krivnjom koja možda, po njemu, nije dovoljno izražena, a Gavrilo Princip samo je simptomatični početak cijele priče. Možda zato naziv pjesme jest u množini: Sasvim neobični slučajevi, a ne: Neobičan slučaj Gavrila Principa i Franje Ferdinanda. Njegovo izvrtanje značenja očito uzima u obzir Gavrila kao srpskog junaka koji je ovdje postao antijunakom jer je pobjegao od dužnosti koje mu je nametnula država, ali time je možda postao junakom u tom drugom svijetu jer nije počinio zločin.

\footnotetext{
${ }^{13} \mathrm{https}: / /$ www.youtube.com/watch?v=A1E9X3DiKK4 (pristup 31. 12. 2015.).
} 
S druge strane, Džambićev tekst možemo tumačiti kao kritiku zapadnjačkog (tj. kolonijalnog) diskursa o Balkanu. Ta poveznica počinjala bi upravo s premještanjem atentata u Distrikt Brčko gdje i danas, kako sam spomenula, na neki način strane sile imaju utjecaj. Pritom činjenica da su u pjesmi F. Ferdinand i G. Princip pobjegli na Kosovo ne bi bilo puko provociranje srpskog nacionalizma nego bi Kosovo bilo tu, baš kao što je i sam G. Princip, zbog svoje mitske pozadine koja se temelji na izvrtanju i/ili pojednostavljivanju informacija kako bi više pogodovale srpskom nacionalizmu. ${ }^{14}$ Naime, iako su oba mita tvorevina srpske povijesti, njihovu su kreiranju "pripomogle" i zapadne sile i to upravo radi lakšeg manipuliranja narodom koji usvaja nacionalističke mitove. ${ }^{15}$ To je još jedan od razloga zbog kojeg je opravdano govoriti o Balkanu u kontekstu kolonijalnog diskursa (Usp. Lazarević Radak 2014:270-271). Stoga Džambić izvrće priču u pjesmi tako da ne pogoduje zapadnjačkom diskursu o Balkanu. Gavrilo se pritom veže s islamskim konotacijama da se pokaže veza različitih naroda i religija koji žive na istom prostoru, a koji su u očima Zapada uvijek na ratnoj nozi (Usp. Todorova 2015:302). U tom kontekstu neočekivani obrat na kraju pjesme, već citirani ludistički stihovi kojima pjesma završava, bio bi posljedica pripisivanja modernizma tradicionalnoj, "nazadnoj" (usp. ibid.) sredini.

\section{MJESTO ZA NACIONALIZAM?}

S obzirom na to da se iz gradiva povijesti sjećam Gavrila Principa kao atentatora na Franju Ferdinanda koji je, iako bosanski Srbin, htio ponajprije ujedinjenje triju većinskih naroda s područja bivše Jugoslavije u jednu državu, iz početka mi nije bilo jasno odakle mjesto za nacionalističke prepirke u komentarima na pjesmi Gavrilo. Odnosno, odakle dolaze drugi tipovi diskursa.

Posegnuvši u dostupne povijesne izvore, odnosno jedine monografije koje sam uspjela pronaći o Gavrilu Principu i Sarajevskom atentatu,

\footnotetext{
${ }^{14}$ https://sh.wikipedia.org/wiki/Kosovski_mit\#Prvi_svetski_rat (pristup 4. 7. 2016.).

${ }^{15} \mathrm{http}$ ://www.e-novine.com/intervju/intervju-drustvo/73390-Kosovski-mit-stvorila-elita. html (pristup 4. 7. 2016.).
} 
otkrivam drugu stranu priče: druge diskurse, kao i razloge za njih. Autori koje sam iščitala, Leo Pfeffer i Slavko Mićanović, nisu povjesničari te im je namjera bila na popularan način predočiti "istinu” oko Sarajevskog atentata. Dok je djelo Lea Pfeffera, inače glavnog suca na optužnici protiv atentatora, usmjereno najviše na sam sudski proces te osuđenike, Mićanovićevo djelo bavi se ponajviše uzrocima i posljedicama Sarajevskog atentata. Slavko Mićanović je književnik, po nacionalnosti bosanski Srbin (baš kao i Gavrilo Princip), a njegova varijanta istine oko priče s Gavrilom Principom prisutna je i u Pfeffera. Oni tvrde da Sarajevski atentat nije bio nikakav nalog srpske države nego je proizašao iz želje pojedinaca okupljenih oko organizacije Mlade Bosne, a potom i Crne Ruke, da se svrgne predstavnik okupatora te da se Jugoslaveni ujedine (Mićanović 1965:224).

Iako su proučavani izvori jednostrani, i ovaj oblik povijesti kao način mišljenja (Connerton 2004:6) pomogao mi je rasvijetliti stvari. Ukratko, te 1914. Bosna i Hercegovina pripadala je Austro-Ugarskoj Monarhiji koja je imala oštre odnose sa susjednom Kraljevinom Srbijom(Mićanović 1965:10). U Hrvatskoj i BiH bila je prisutna jaka mađarizacija (Pfeffer 1938:22), pa se javljalo nezadovoljstvo među narodom, pri čemu je najaktivnija bila omladina. U to vrijeme nastaje pokret Mlada Bosna u Bosni i Hercegovini (Ibid. 52) čiji je pripadnik bio Gavrilo Princip. Njezinim osnivačem smatra se Vladimir Gaćinović koji se boravkom u Beogradu pridružio organizaciji Ujedinjenje ili Smrt, poznatijom pod nazivom Crna ruka (Ibid. 53). On je radio na uspostavljanju veza između revolucionarno raspoloženih jugoslavenskih omladinaca, kako u Srbiji i BiH tako i u inozemstvu. Glavna obilježja Mlade Bosne bila su antiaustrijski stav i jugoslavenska orijentacija (Ibid. 54). Tako je Gaćinović jednom prilikom pisao Gavrilu Principu i Danilu Iliću da organiziraju atentat na Franju Ferdinanda; trenutak kad su saznali da dolazi u Sarajevo nametnuo se sam po sebi kao savršen (Ibid. 57). Ovo je bio tek jedan od atentata na tom teritoriju, šesti na području Hrvatske i BiH, ${ }^{16}$ ali prvi uspjeli, a osnivači Crne ruke sudjelovali su 1903. u ubojstvu Aleksandra Obrenovića i njegove žene, kraljice Drage. ${ }^{17}$ Upravo

\footnotetext{
${ }^{16}$ https://sh.wikipedia.org/wiki/Mlada_Bosna\#Neuspeli_atentat_na_cara_Franju_ Josifa_.281910.29 (pristup 2. 1. 2016.).

${ }^{17}$ https://bs.wikipedia.org/wiki/Aleksandar_Obrenovi\%C4\%87 (pristup 2. 1. 2016.).
} 
ta povezanost Mlade Bosne sa zločinačkom organizacijom Crne ruke, kao i činjenica da su atentatori većinom srpske nacionalnosti ${ }^{18}$ te da su nabavili oružje u Beogradu, bile su osnova da Austro-Ugarska osudi Srbiju kao inicijatora ovog atentata (Horvat 1967:129) te joj objavi rat aktivirajući niz savezništava koja su potom pokrenula lančanu reakciju objava rata. Unutar mjesec dana veći je dio Europe zaratio. ${ }^{19}$

S obzirom na to da su odnosi između Austro-Ugarske i Srbije bili i prije rata napeti, činjenicu da je upravo 28. lipnja odabran kao datum posjeta Franje Ferdinanda, Srbi u BiH doživjeli su kao neprijateljski čin AustroUgarske (Mićanović 1965:85). Naime, upravo je tad srpski nacionalni praznik - Vidovdan, k tomu i prvi nakon Balkanskih ratova gdje su Srbi trebali "slaviti osvećeno Kosovo". Nakon atentata, uz lokalne vlasti, neprijateljstvu spram Srba pridružili su se i stanovnici Sarajeva - smatralo se da je atentat izraz neprijateljskih osjećaja cijeloga srpskog stanovništva te su bili demolirani mnogi srpski dućani i ustanove u samom Sarajevu (Ibid. 132; Horvat 1967:19). Jer iza navodnih naredbi Srbije nije se krila jugoslavenska ideja nego velikosrpska (Mićanović:193-194). A konačna presuda kao da je bila više usmjerena protiv Srbije, a ne optuženih. Iako su se atentatori sami predstavljali kao ljudi koji su znali što žele, na suđenju su ih predstavljali kao fanatike, zavedene ličnosti koje su poslužile drugima za njihove mračne ciljeve (Ibid. 221).

Čini se da je ovakvo dualno shvaćanje prisutno i danas, što uključuje analizirane pjesme: dok Zoster u neutralnijoj slici možda više naginje Gavrilovoj samosvijesti, DiV stihom “delegati javili” inicira da je zapovijed došla odozgo. Također u njegovoj verziji Gavrilo Princip sasvim slučajno pristaje obaviti atentat napivši se ("Mrtav pijan Gavrilo samog sebe ponudi. Delegati shvatiše, Princip će da uradi"). ${ }^{20}$

$\mathrm{K}$ tomu, i sama nailazim na dualnosti: uvjerena u verziju koje se sjećam iz udžbeničkih redaka, da je Princip ubio i umro za ideju jedne

\footnotetext{
${ }^{18}$ U atentatu su sudjelovali i jedan Hrvat - Ivo Kranjčević (samo u skrivanju oružja), te jedan musliman - Muhamed Mehmedbašić (jedan od potencijalnih atentatora) (Pfeffer 1938:75).

${ }^{19}$ https://hr.wikipedia.org/wiki/Prvi_svjetski_rat (pristup 2. 1 .2016.).

${ }^{20}$ Naravno, ako pjesmu Sasvim neobični slučajevi promatramo isključivo kao kritiku zapadnjačkog diskursa (što je bilo drugo tumačenje koje sam iznijela u analizi), ovim stihovima Džambić upućuje upravo na mišljenje Zapada, a ne nužno svoje.
} 
jugoslavenske nacije, u nasumično odabranom udžbeniku povijesti u knjižnici pronalazim definiciju Mlade Bosne kao prosrpske (terorističke) organizacije koja je željela da se BiH priključi Srbiji, a o jugoslavenstvu ne pronalazim ni riječi (Kolar-Dimitrijević et al. 2004:34). Ova mala epizoda dobro ilustrira da već od teme Sarajevskog atentata u školskim udžbenicima na području bivše Jugoslavije nailazimo na etnocentrične navode o kolektivnoj prošlosti i klice za stereotipe (Koulouri 2002:31) te da i ona govori mnogo toga o međususjedskim odnosima na zapadnom Balkanu.

Kada Gavrilo Princip identificira i predstavlja političke entitete, onda govorimo o njemu kao političkom simbolu (Azaryahu 1999:256) s najmanje trojakim značenjem (koje se grana u potkategorije što ću prikazati u idućim poglavljima). Dok jedni vežu njegov čin s jugoslavenstvom tretirajući takvu ideju, između ostalog, kao htijenje pomirenja na ovim prostorima (primjerice, to je mišljenje njegovih živućih rođaka), ${ }^{21}$ za druge je Princip simbol borbe potlačenog naroda protiv velesila, a takav se diskurs najčešće zauzima prilikom neutralnog pričanja o Gavrilu Principu, ali se iza njega mogu kriti neke druge namjere, primjerice zastupanje G. Principa kao simbola u duhu srpskog nacionalizma, što bi bilo treće značenje njegova simbola. Tako nešto bilo je vidljivo u govoru srpskih uglednika za vrijeme svečanog otkrivanja Principova spomenika u Sarajevu 2014. ${ }^{22}$ i njegovu premještanju u Beograd na Vidovdan 2015. ${ }^{23}$ Shvaćanje G. Principa kao političkog simbola u svrhu jačanja srpskog identiteta jest najsnažnije jer dolazi od službenih vlasti, pa tako on ujedno postaje i kanonski simbol. Kao takav, sažima temelje i doktrine aktualne ideologije te je reproducira jasno i koncizno (Ibid. 259). Osobe koje se spominju u javnom životu važna su sastavnica povijesnog sjećanja (Ibid. 262), a posebice ako im se podižu spomenici. S obzirom na to da je manipulacija sjećanjem prouzrokovala ratove na ovdašnjim prostorima (Müller 2004:222), ovakvi javni ispadi oko

${ }^{21} \mathrm{http}$ //www.blic.rs/vesti/republika-srpska/nikola-princip-vreda-kada-kazu-da-jegavrilo-bio-srpski-nacionalista/zt8116y (pristup 4. 1. 2016.).

$22 \mathrm{http}$ ://www.blic.rs/vesti/drustvo/spomenik-gavrilu-principu-otkriven-u-istocnomsarajevu/12dxtnb (pristup 4. 1. 2016.).

${ }^{23} \mathrm{http} / / /$ dnevnik.hr/vijesti/svijet/beograd-otkriven-spomenik-gavrilu-principu---390978. html (pristup 4. 1. 2016.). 
nejasnih stvari u povijesti ${ }^{24}$ nisu beznačajni, posebice na Balkanu koji, čini se, nije još pomiren sa svojom prošlošću.

Sažeti uvid u druge tipove diskursa naznačio mi je da se nejasnost oko lika i djela Gavrila Principa očitava i izvan popularne kulture te da se kategorije koje izdvajam u idućem poglavlju, potkrijepljene prije svega YouTube komentarima, s više ili manje sličnosti mogu primijeniti i na druge diskurse, što službene, što neslužbene.

S obzirom na to da je Gavrilo Princip dio povijesti stare 100 godina, mi ga se kao pojedinci ne možemo sjećati, ali on je postao dio naše kulture: medija i povijesti koje učimo u školi. Stoga o njemu možemo pričati u kontekstu kolektivnog pamćenja (Halbwachs, prema Assman 2006:51-52) jer je naše pamćenje o njemu određeno kolektivno, društvenom okolinom. Bolje će to pojasniti distinkcija podvrsta kolektivnog pamćenja koje Assman naziva komunikacijskim i kulturalnim (Usp. Ibid. 59). Princip je živio prije 100 godina, pa u našem sjećanju opstaje putem kulturalnog pamćenja, a to znači da ima čvrsta uporišta u prošlosti koju nam prenose neki autoriteti, tj. osobe koje imaju "punomoć na znanje" (Ibid. 66), pa Principa pamtimo iz dokumentarnih filmova, povijesnih lekcija, enciklopedija itd. S druge strane, komunikacijsko pamćenje pripada određenoj grupi, odnosi se na sjećanja iz recentne prošlosti, to je generacijsko pamćenje koje odgovara sjećanju stvorenom osobnim jamčenim i komuniciranim iskustvom te mu je raspon od tri do četiri generacije (Ibid. 63). Stoga smatram da je G. Princip zbog stigmatizacije Srba oko početka Prvoga svjetskog rata postao simbol njihove žrtve i hrabrosti, pa je proživljeno iskustvo stvoreno oko njegova lika i djela jednostavno prešlo u komunikacijsko pamćenje (koje odgovara krajnjem vremenskom rasponu iz definicije). S druge strane, kod ostalih naroda s područje bivše Jugoslavije, on je prepušten kulturalnom pamćenju; naše znanje o njemu ovisi o autoritetima koji nam ga prenose.

\section{INTERNET KAO MJESTO SUSRETA OPREČNIH MIŠLJENJA (ANALIZA KOMENTARA)}

Glazbena scena alternativne (rock) glazbe na prostoru bivše Jugoslavije gotovo funkcionira kao jedna, kao što sam navela: $D i V$ je iz

${ }^{24} \mathrm{http}: / /$ balkans.aljazeera.net/vijesti/beograd-podize-spomenik-gavrilu-principu (pristup 4. 1. 2016.). 
Brčkoga $(\mathrm{BiH})$, a trenutačno živi i djeluje u Zagrebu (RH). Prvi album 2009. godine objavio je u zagrebačkoj diskografskoj kući Slušaj najglasnije. Osim toga, činjenica da je 2015. godine pobijedio na slovenskom festivalu KantFest, a imao je i nekoliko nastupa u Srbiji, govori da njegov opus, iako underground, prelazi državne granice. ${ }^{25}$ Ovaj slučaj oprimjeruje i Zoster svojim nastupima u svrhu promocije albuma Srce uzavrelo u Sarajevu, Mostaru, Zagrebu, ali i Novom Sadu na festivalu Exit. ${ }^{26}$

S obzirom na to da je danas internet glavni medij tržišta i komunikacije, dostupnost i povezanost glazbene scene još je veća. Internet također omogućuje anonimno komentiranje i iznošenje vlastitog mišljenja, ali i komunikaciju s izvođačem ili drugim slušateljima, a takav je i slučaj s pjesmom Gavrilo na YouTube mreži. Tretiramo ga kao prostor, iako virtualni, jer je aktivni sustvaratelj međuljudskih odnosa, identiteta, pa i zajednica (Gulin Zrnić, prema Vukušić 2011:402). No internet, odnosno društvenu mrežu YouTube, u ovom kontekstu važno je spomenuti kao potrošački oblik popularne kulture. Pjesma Gavrilo u tom je smislu proizvod u diskurzivnoj formi. Tekstopisac pjesme jest pošiljatelj poruke koju je na taj način kodirao, a na publici je da je dekodira (Hall 2006:128), prevede, ponovno preobliči kako bi kruženje proizvoda bilo potpuno. Ako značenje proizvoda ostane nerazumljivo, ne može doći do potrošnje, a ako nije izraženo u praksi, nema učinka (Ibid.). Komentari na Zosterovu pjesmu ${ }^{27}$ upravo svjedoče pokušaje dekodiranja, a rasprave, koje ponekad prerastaju u svađe, posljedica su žive prakse različitog shvaćanja proizvoda, tj. njegove poruke i samim time posljedica njegova ostvarenja (Usp. Ibid. 129).

Komentari se mogu sadržajno podijeliti u više kategorija. Prva su kategorija komentari koji vide Gavrila Principa kao atentatora/terorista i slično: "Čemu pjesma o atentatoru?" (damnun) $)^{28}$ ili "Klasični terorista."

\footnotetext{
${ }^{25} \mathrm{http}$ ://jecakizvode.wix.com/div-djecak-iz-vode\#!about/c10fk (pristup 7. 2. 2016.).

${ }^{26} \mathrm{http}: / /$ www.klix.ba/magazin/muzika/zoster-treci-put-na-exit-u/150604084 (pristup 7. 2. 2016.).

${ }^{27}$ https://www.youtube.com/watch? $\mathrm{v}=\mathrm{qWwxA} 8 \mathrm{HzjVc}$ (pristup 3. 1. 2016.).

${ }^{28}$ Komentare prilagođujem standardnoj transkripciji i ortografiji, izostavljajući također emotikone, ali ostavljam ih u jeziku/dijalektu kojim su napisani ne prilagođavajući ih na hrvatski standardni jezik, a u zagradi navodim nadimak korisnika.
} 
(Ivan Grozni). U tu kategoriju ubrajam i komentare koji Gavrila vide kao čovjeka koji je izginuo za srpski nacionalizam (u nečije tuđe ime) o čemu sam ranije raspravljala, npr.: "Zoster počeo pjevati četničke pjesme hahaha" (grind corer), ili:

Pa naravno da je tada zapamćen kao heroj kada je nakon njegovog atentata uništeno Austrougarsko carstvo, a $\mathrm{BiH}$ je postala dio Kraljevine Srba, Hrvata i Slovenaca, kojom je vladala srpska kraljevska porodica ... (damnun).

Ovaj komentar osvrće se na činjenicu da je zaista stvorena zajednica Jugoslavena što je Princip htio, ali je njome vladala srpska porodica, pa je to svejedno realizacija velikosrpske ideje. Idući se komentar pak direktno koncentrira na činjenicu koja je ranije bila raspravljena, a to je da je Gavrilo Princip bio samo marioneta srpskih državnika:

... Princip je bio običan pulen, mladi dječak kojeg su crni umovi crne ruke poslali da uradi nešto za šta su oni imali političku pozadinu, a nisu imali muda sami uraditi. (Ne Dam).

Upravo u taj kontekst smještam i drugu kategoriju komentara - koji zbog srpskog nacionalizma slave Gavrila kao junaka, u njima je vidljiva velikosrpska ideologija. Pritom prvi komentar ne sumnja u prosrpsku pozadinu organizacija okupljenih oko Sarajevskog atentata, spominje i Apisa (Dragutina Dimitrijevića), osnivača Crne ruke, ${ }^{29}$ te implicira kako su nakon pobjedničkih ratova u mirovnim sporazumima Srbi izgubili i da njihova dominacija tek dolazi. Drugi komentar osvrće se na dominaciju Srba na ovim područjima i njihovu nadmoć nad ostalim narodima koje naziva pogrdnim imenima; u ovom komentaru nije sadržana prognoza srpske dominacije kao u prvom, nego samo prijetnja:

"Naše će sjene hodati po Beču, lutati po dvoru i plašiti gospodu" Živeo Gavrilo Princip, Mlada Bosna, Apis i Crna Ruka! Braćo Srbi, u dva svetska rata smo pobedili, u dva mira izgubili. Srećan nam Treći Svetski Rat i buduća dominacija! Ili pukovnik ili pokojnik! (Faust Fon Eugen)

${ }^{29} \mathrm{https}$ ://hr.wikipedia.org/wiki/Dragutin_Dimitrijevi\%C4\%87_Apis (pristup 7. 2. 2016.). 
Ljudi, mogu oni da pričaju i ustaše i balije i svi šta hoće, ali su Srbi za njih uvijek bili bogovi, a to će i ostati. Srba se boje pa ih zato stalno napadaju, a da se srpski moral i jaka volja otme kontroli satrali bi ih ko Putin Ukrajinu. I zato ove što vrijeđaju srpski narod molim da se poklope i šute. (Milos Dragojevic).

Također je tu zanimljivo komentiranje na ćirilici i/ili primjećivanje zanimljivih podudarnosti sa simbolima pravoslavlja: "A fino traje pjesma. 3:33" (BijeliOblak92; originalno napisano na ćirilici).

Mnogi od ovih komentara funkcioniraju kao protuargumenti u započetim raspravama; dvije najrazvijenije rasprave, koje ovdje zbog bolje preglednosti neću u cijelosti prikazati, izrazito su nacionalističkog naboja. Jedna se rasprava vrti oko odnosa Srba i Hrvata (započeto komentarom da je Zoster hrvatski bend te zašto ga uopće Srbi slušaju) raspravljajući o dominaciji jedne odnosno druge nacije, a druga se rasprava vrti oko odnosa Srba i Muslimana/Bošnjaka u BiH.

Kako bi se ublažili nacionalistički ispadi, javlja se treća kategorija komentara - koji pokušavaju istaknuti Principovo jugoslavenstvo: "Gavrilo se izjašnjavao kao Jugosloven, bio [je] za ujedinjenje svih Južnih Slavena." [Шон Девлин (Šon Devlin); originalno na ćirilici].

On je bio taj koji jeste spojio taj naš narod i na krvav način spriječio da nas Austrougari i Turci prcaju u sve rupe. Znači, zaustavio je pokolj i stvorio Jugoslaviju. Zaustavio mržnju između naroda Balkana i postao prva žrtva koja je stvorila Jugoslaviju. Jednu naciju. Šta sam misliš zašto je na sličan način počelo svo sranje 90-ih? Moje je mišljenje da se masovna većina prestala osjećati jednom nacijom ... (Jass Gasi).

Jass Gasi čak ide toliko daleko da jugoslavenstvo Gavrila Principa proglašava ključnim za bilo kakvu realizaciju takve države nakon 1914. Naziva ga prvom žrtve Jugoslavije, a svi sukobi na ovim prostorima samo su posljedica činjenice da se ne osjećamo kao jedan narod.

Iduću kategoriju čine komentari koji ističu samu Principovu hrabrost i činjenicu da je želio svrgnuti okupatora koji također najčešće imaju funkciju smirivanja započetih nacionalističkih tenzija: 
Mene čudi što bi bilo ko u Bosni imao nešto protiv Gavrila... pucao je u čovjeka koji je okupirao tu istu Bosnu, zar ne? Veličaju Ferdina[n] da kao da je imam ... (najed ajivul)

... sreća što je bilo i ovakvih kao što je ovaj junak o kome je ova pjesma. Sarajevo treba da bude ponosno svojim najhrabrijim sinom, a ne da ga se naziva teroristom, nije terorizam braniti svoju kuću i svoju slobodu. BUNT! (leonprof100)

Tu bih pridodala kratke odgovore poput "Svi smo mi Gavrilo" (Pekez Igor) ili "Gavrilo Princip je za mene heroj" (Marko Vasilic) te komentare koji citiraju samog Gavrila Principa, npr. Penga Pengic u cijelosti donosi njegovu jedinu zapisanu pjesmu.

U posljednju kategoriju ubrajam ostale neutralizirajuće komentare: oni koji citiraju samu pjesmu ili intervjue Marija Knezovića u kojima navodi da tu nisu važne povijesne okolnosti nego sam Gavrilo kao osoba, te zatim oni koji tvrde da je glazba bitnija te poručuju ostalima da prepirke presele negdje drugdje, od kojih je najpopularniji lakonski komentar "Balkancima ZABRANITI KOMENTARISANJE!" (mustafa omeragic). U ovoj kategoriji zaključno izdvajam komentar s visokom razinom neutraliziranja koji sumira čitavu situaciju objašnjavajući da je umjetnička sloboda (pjesma) kategorija koja bi se trebala promatrati izvan politike:

U slobodnim zemljama izvan totalitarizma, diktatura, vjerskih i ostalih oligarhija postoji nešto što se zove umjetnička sloboda, zato Gavrilo (Flemming Rassmussenn).

Dakle, komentare sam svrstala u pet kategorija, od kojih prvu čine komentari koji vide G. Principa kao atentatora ili terorista (gdje sam uvrstila i one koji komentiraju sam teroristički čin te one koji ga vide kao posljedicu velikosrpske ideje); drugu kategoriju čine komentari koji ga vide kao srpskog junaka; treću koji ga vide kao čovjeka koji je izginuo i ubio za ideju jugoslavenstva; četvrtu kategoriju čine komentari o Gavrilu kao junaku, ali u smislu da predstavlja malog čovjeka koji se bori za velike stvari, tj. ideale, tu se junaštvo ne iskorištava u druge svrhe kao što je u drugoj kategoriji. Konačno, petu kategoriju nazvala sam neutralnom, a tu su komentari koji žele smiriti čitavu situaciju i naglasiti umjetničku komponentu pjesme 
Gavrilo. Ovakva se analiza uklapa u početnu tezu da Gavrila Principa možemo tumačiti kao prizmu u kojoj se različiti načini interpretiranja (nacionalne) povijesti križaju, ali i suprotstavljaju zbog svojih ideoloških opozicija (Belaj i Škrbić Alempijević 2014:81).

Razlog zbog kojih sam neke kategorije odvojila kao zasebne (npr. G. Princip kao junak - druga i četvrta kategorija), a neke samo kao potkategorije (npr. G. Princip kao atentator u prvoj kategoriji te Gavrilovo jugoslavenstvo u trećoj kategoriji sa svim pripadajućim potkategorijama) bio je čisto zbog količine ili dominacije samih tih kategorija te lakše preglednosti. Činjenice da bi se ove kategorije dale još više podijeliti, a kako vrijeme prolazi, novi komentari još stižu na postojećoj YouTube stranici, samo svjedoče ambivalentnost Gavrila Principa kao znaka (Peirce, prema Fikfak 2014:8). Odnosno, on nije samo nacionalno određen (pa nećemo raspravljati o njemu samo kao provoditelju velikosrpske ili jugoslavenske ideje) nego je određen i dobno (značenje mu se mijenja s generacijama, zato se javljaju nove kategorije neutralnijeg podznaka) i klasno (različito tumačenje jugoslavenstva).

\section{ULAZAK U POPULARNU KULTURU KAO POMIRENJE}

Ulazak Gavrila Principa u popularnu kulturu promatram kao vid pomirenja s prošlošću. Prestaje biti važno je li on heroj ili zločinac, te koje su bile (in)direktne posljedice njegova čina. Činjenica da je to bilo prije 100 godina dovoljno govori za sebe. Pomirenje s prošlošću znači mirnu sadašnjost, neopterećenu "pravom istinom" koja je ionako nedokučiva i uvijek višedimenzionalna. Popularna kultura prihvaća potencijalno prazna i opća mjesta te se s njima igra, upisujući nova značenja te izvrćući postojeća, kao što i sam Mario Knezović tvrdi u intervjuu o toj pjesmi:

To je neka priča koju znamo svi, ja sam je samo izbanalizirao. Priča ima više slojeva, nekad zvuči preozbiljno, nekad je ironična i to jeste ideja, da se s tim uvijek možeš igrati. Kad sam se rodio, ta priča je postojala i moje je pravo da imam neki odnos prema njoj, ali on nije okoštan, on je uvijek propitivajući. Nije ni za, a ni protiv. Jednostavno je to igra sa nekim općim mjestima. (Mario Knezović) $)^{30}$

\footnotetext{
${ }^{30} \mathrm{http}$ //www.klix.ba/magazin/muzika/mario-knezovic-kad-je-u-pitanju-nacionalizammi-smo-kao-djeca-koja-kasne-u-razvoju/150609067 (pristup 4. 1. 2016.).
} 
S time se igra i Edin Džambić u svojoj pjesmi, ali na veoma pronicljiv i, rekla bih, kontroverzan način, pa je možda olakotna okolnost što je Dječak iz Vode dio underground scene, čisto zbog toga što je tako spriječena oluja burnih reakcija.

Popularnu kulturu u ovom kontekstu također promatram kao poseban oblik reaktiviranja i rekonstrukcije prošlosti i sjećanja. Neka sjećanja naizgled su oduvijek prisutna, i povjesničari ne mogu ljudima predočiti znanstvenu istinu, ali oni nisu jedini koji oblikuju znanje o prošlosti (Brkljačić i Prlenda 2006:9). Ovdje je prikazano kako popularna glazba može oblikovati znanje o prošlosti, reinterpretirati možda već postojeće znanje te kako se u njoj manifestira društveno sjećanje. Gavrilo Princip je primjer junaka (?) koji je utkan u kolektivno pamćenje (Assman i Czaplicka, prema Fikfak 2014:8), a kolektivno se pamćenje hrani upravo novim sadržajem koje crpi iz različitih medija: službenih, javnih i polujavnih diskursa (Ibid.), što uključuje i popularnu kulturu.

Iako je možda popularna kultura u stanju izvrtati prijeporna mjesta društvenog sjećanja igrajući se s njima, čini se da njezin potrošački oblik (u ovom slučaju internet i društvena mreža YouTube) za to nije spreman. On postaje mjesto dekodiranja, ali ne jednodimenzionalnog što svejedno ide $\mathrm{u}$ korist ostvarenja pjesme (Usp. Hall 2006:129).

Za kraj, Gavrila Principa možemo promatrati kao simbol čitavog Balkana koji se često veže uz rat. A prijašnji stereotipi o Balkanu na koje se ponekad moglo naići kao nazadnom, primitivnom i barbarskom, nakon Prvoga svjetskog rata samo su postali još više fiksirani i prošireni kroz sliku nepromjenjivog Balkana (Todorova 2015:301-302). Dakle, svijet ga vezuje uz rat (kako Balkan tako i Gavrila Principa), dok je zapravo priča mnogo kompleksnija, istina gotovo nedokučiva i kao takva često podložna manipulacijama što u najmanju ruku ilustriraju verbalni sukobi u analiziranim komentarima.

\section{LITERATURA}

ANIĆ, Vladimir. 2003. “Sutlija”, “Šeher”. U Veliki rječnik hrvatskoga jezika. Zagreb: Novi liber, 1508, 1529.

ASSMANN, Jan. 2006. "Kultura sjećanja”. U Kultura pamćenja i historija, ur. Drago Roksandić. Zagreb: Golden marketing - Tehnička knjiga, 46-79. 
AZARYAHU, Maoz. 1999. "Politički simboli u svakidašnjici. Polisistemski pristup istraživanju”. Etnološka tribina, vol. 29/22:255-267. http://hrcak.srce.hr/80954

BELAJ, Marijana i Nevena ŠKRBIĆ ALEMPIJEVIĆ. 2014. "Remembering "the Father of the Contemporary State of Croatia"”. Traditiones, vol. 43/1:79-109. https://doi. org/10.3986/TRADITIO2014430107

BREGLEC, Zrinka. 2015. "Balkan kao prazan ili lebdeći označitelj u hrvatskom javnom i političkom diskurzu”. U Svijet stila, stanja stilistike. Zbornik radova prezentiranih na istoimenom kolokviju održanom 13. veljače 2015. na Filozofskom fakultetu u Zagrebu, ur. Anera Ryznar. Zagreb: Filozofski fakultet Sveučilišta u Zagrebu. http://stilistika.org/breglec (pristup 1. 7. 2016.).

BRKLJAČIĆ, Maja i Sandra PRLENDA. 2006. “Zašto pamćenje i sjećanje?”. U Kultura pamćenja i historija, ur. Drago Roksandić. Zagreb: Golden marketing - Tehnička knjiga, 9-18.

CONNERTON, Paul. 2004. Kako se društva sjećaju. Zagreb: Antibarbarus.

DUDA, Dean. 2006. “Užas je moja furka'. Socijalistički urbani imaginarij Branimira Štulića”. U Devijacije i promašaji. Etnografija domaćeg socijalizma, ur. Lada Čale Feldman i Ines Prica. Zagreb: Institut za etnologiju i folkloristiku, 95-120.

FIKFAK, Jurij. 2014. "Leaders and heroes of the nation". Traditiones, vol. 43/1:7-11. https://doi.org/10.3986/traditio2014430101

FRIT, Sajmon [i. e. Simon FRITH]. 1987. Sociologija roka. Beograd: Istraživačkoizdavački centar SSO Srbije - Centar za istraživačku, dokumentacionu i izdavačku delatnost PK SSO Jugoslavije.

GEE, James Paul. 1999. An introduction to discourse analysis: theory and method. London - New York: Routledge.

HALL, Stuart. 2006. "Kodiranje/dekodiranje”. U Politika teorija. Zbornih rasprava iz kulturalnih studija, ur. Dean Duda. Zagreb: Disput, 127-139.

HORVAT, Josip. 1967. "Prolog”. U Prvi svjetski rat. Panorama zbivanja 1914 - 1918. Zagreb, 9-141.

JØRGENSEN, Marianne i Louise J. PHILLIPS. 2002. Discourse Analysis as Theory and Method. London: Sage Publications.

KOLAR-DIMITRIJEVIĆ, Mira, Hrvoje PETRIĆ i Jakša RAGUŽ. 2004. "Sarajevski atentat". U Povijest 4: udžbenik iz povijesti za 4. razred gimnazije. Samobor: Meridijani, 34.

KOUlOURI, Christina, ur. 2002. Clio in the Balkans. The Politics of History Education. Thessaloniki: Center for democracy and reconciliation in Southeast Europe.

LACLAU, Ernesto. 2007. Emancipation(s). New York - London: Verso.

LACLAU, Ernesto i Chantal MOUFFE. 1985. Hegemony and Socialist Strategy. New York - London: Verso. 
LAZAREVIĆ RADAK, Sanja. 2014. "Orijentalistički stereotipi i balkanistički diskurs: dva veka popularne književnosti o Balkanu". U Sarajevski filološki susreti II. Zbornik radova (knjiga II), ur. Sanjin Kodrić i Vahidin Preljević. Sarajevo: Bosansko filološko društvo, 269-281.

MIĆANOVIĆ, Slavko. 1965. Sarajevski atentat. Zagreb: Stvarnost.

MÜLLER, Jan-Werner. 2004. Memory and Power in Post-War Europe. Studies in the Presence of the Past. Cambridge: Cambridge University Press.

PFEFFER, Leo. 1938. Istraga u Sarajevskom atentatu. Zagreb: Nova Evropa.

TODOROVA, Marija. 2015. Imaginarni Balkan. Zagreb: Ljevak.

VUKUŠIĆ, Ana Marija. 2011. "O prožetosti virtualnoga i stvarnoga. Primjer jednog 'lokalnog' web-foruma". U Mjesto. Nemjesto. Interdisciplinarna promišljanja prostora i kulture, ur. Jasna Capo i Valentina Gulin Zrnić. Zagreb: Institut za etnologiju i folkloristiku, 394-399.

\section{INTERNETSKI IZVORI}

“About". Dječak iz Vode. http://djecakizvode.wix.com/div-djecak-iz-vode\#!about/c10fk (pristup 7. 2. 2016.).

"Beograd: Otkriven spomenik Gavrilu Principu". Dnevnik.hr, 28. lipnja 2015. http:// dnevnik.hr/vijesti/svijet/beograd-otkriven-spomenik-gavrilu-principu---390978. html (pristup 4. 1. 2016.).

"Beograd podiže spomenik Gavrilu Principu". Al Jazeera Balkans, 7. lipnja 2015. http:// balkans.aljazeera.net/vijesti/beograd-podize-spomenik-gavrilu-principu (pristup 4. 1. 2016.).

BAKOTIN, Jerko. 2012. "Pozajmljeni intervju: Olivera Milosavljević, istoričarka. Kosovski mit stvorila je elita". E-novine, 25. listopada. http://www.e-novine.com/ intervju/intervju-drustvo/73390-Kosovski-mit-stvorila-elita.html (pristup 4. 7. 2016.).

ČOLAK, Lejla. 2015. "Mario Knezović: Kad je u pitanju nacionalizam, mi smo kao djeca koja kasne u razvoju". Klix.ba, 10. lipnja. http://www.klix.ba/magazin/muzika/ mario-knezovic-kad-je-u-pitanju-nacionalizam-mi-smo-kao-djeca-koja-kasne-urazvoju/150609067 (pristup 4. 1. 2016.).

DEVČIĆ, Matej. 2015. "Zoster ogolio svakog od nas". Muzika.hr, 27. svibnja. http:// www.muzika.hr/clanak/50712/albumi/zoster-ogolio-svakog-od-nas.aspx (pristup 28. 12. 2015.).

DJEČAK IZ VODE. 2014. "Sasvim neobični slučajevi”. YouTube, 28. lipnja. https://www. youtube.com/watch? $\mathrm{v}=\mathrm{A} 1 \mathrm{E} 9 \mathrm{X} 3 \mathrm{DiKK} 4$ (pristup 31. 12. 2015.).

ĐURIN, Sanja. 2013. "Teorija diskursa - razvoj ideje". Gong.hr. http://www.gong.hr/ media/uploads/gong_ljetna_skola___durin.pdf (pristup 1. 7. 2016.) 
“Dragutin Dimitrijević Apis”. Wikipedia. https://hr.wikipedia.org/wiki/Dragutin Dimitrijevi\%C4\%87_Apis (pristup 7.2. 2016.).

“Kosovski mit”. Wikipedia. https://sh.wikipedia.org/wiki/Kosovski_mit\#Prvi_svetski_rat (pristup 4. 7. 2016.).

"Nikola Princip: Vređa kada kažu da je Gavrilo bio srpski nacionalista”. Blic, 26. lipnja, 2014. http://www.blic.rs/vesti/republika-srpska/nikola-princip-vreda-kada-kazuda-je-gavrilo-bio-srpski-nacionalista/zt8116y (pristup 4. 1. 2016.).

"Popularna kultura". Hrvatska enciklopedija. http://www.enciklopedija.hr/ natuknica. aspx?id=49511 (pristup 7. 2. 2016.).

"Prvi svjetski rat". Wikipedia. https://hr.wikipedia.org/wiki/Prvi_svjetski_rat (pristup 2. 1. 2016.).

“Spomenik Gavrilu Principu otkriven u Istočnom Sarajevu”. Blic, 27. lipnja 2014. http:// www.blic.rs/vesti/drustvo/spomenik-gavrilu-principu-otkriven-u-istocnomsarajevu/12dxtnb (pristup 4. 1. 2016.).

"Suvremena tumačenja". https://sh.wikipedia.org/wiki/Mlada_Bosna\#Neuspeli_atentat_ na_cara_Franju_Josifa_.281910.29 (pristup 2. 1.2016.).

ŠILJEG, Domagoj. 2014. “tekst šesti”. Dječak iz vode (kultivator.hr), 28. studenoga. http:// djecakizvode.wix.com/div-djecak-iz-vode\#!blank/c10kj (pristup 28. 12. 2015.).

“Tamnovanje i smrt”. Wikipedia. https://sh.wikipedia.org/wiki/Gavrilo_Princip (pristup 7. 1. 2016.).

“Ubistvo". Wikipedia. https://bs.wikipedia.org/wiki/Aleksandar_Obrenovi\%C4\%87 (pristup 2. 1. 2016.).

ZOSTER. 2014. "Gavrilo". YouTube, 19. lipnja. https://www.youtube.com/ watch? $\mathrm{v}=\mathrm{qWwxA8HzjVc}$ (pristup 3. 1. 2016.).

“Zoster opjevao slavnog 'Gavrila"'. Hercegovina.info, 30. lipnja 2014. http://www. hercegovina.info/vijesti/show/showbiz/zoster-opjevao-slavnog-gavrila (pristup 28. 1. 2016.).

“Zoster treći put na EXIT-u”. Klix.ba, 4. lipnja 2015. http://www.klix.ba/magazin/muzika/ zoster-treci-put-na-exit-u/150604084 (pristup 7. 2. 2016.). 
Katarina Lukec

"FOR SOME HE IS A HERO, FOR OTHERS A CRIMINAL" - GAVRILO PRINCIP IN POPULAR CULTURE A HUNDRED YEARS AFTER THE ASSASSINATION IN SARAJEVO

In this paper the author looks at how the life and work of Gavrilo Princip are being used in popular culture by focusing on songs by two bands from Bosnia and Herzegovina, i.e. Zoster and Dječak iz vode (A boy who emerged from the water), which thematize the assassination in Sarajevo. The role of popular culture in social memory is considered and researched by way of analysing the songs and comments on YouTube.

Keywords: Gavrilo Princip, popular culture, the Balkans, social memory

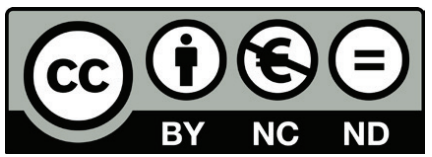

Articles published in this journal are Open Access and can be distributed under the terms and conditions of the Creative Commons license Attribution-NonCommercial-NoDerivatives 4.0 (http://creativecommons.org/licenses/by-nc-nd/4.0/) 
